\title{
The Cycling Pool of Cells within Human Brain Tumors: In Situ Cytokinetics Using the Monoclonal Antibody Ki-67
}

\author{
Ana Maria Tsanaclis, Françoise Robert, Jean Michaud and Steven Brem
}

\begin{abstract}
Brain tumor growth results from the relative proportion of cells contained in three populations: a) cycling/proliferative; b) quiescent $\left(\mathrm{G}_{\mathrm{O}}\right) / \mathrm{static}$, and $\left.\mathrm{c}\right)$ terminally differentiated/dying. The cycling compartment can be detected by the mouse monoclonal Ki-67 antibody, an available, rapid, safe, sensitive, and specific method for immunostaining of proliferative cells. We report the $\mathrm{Ki}-67$ labeling index (LI) in 48 brain tumors. Malignant brain tumors have elevated LIs, ranging from $6.0 \%$ to $56.9 \%$ : anaplastic astrocytoma, $8.0 \pm 7.3$; glioblastoma multiforme, $10.1 \pm 4.2$; germinoma, 11.7 ; medulloblastoma, $13.1 \pm 6.6$; metastases, $40.3 \pm 13.1$. By contrast, slow-growing tumors showed lower values $(P<.001)$, approaching $1 \%$ : acoustic schwannoma, $0.4 \pm 0.6$; pituitary adenoma, $1.3 \pm 1.9$; meningioma, $1.2 \pm 1.2$; low-grade astrocytoma, $<1$; pilocytic astrocytoma, 5.6. Human brain tumors can therefore be ranked according to the percentage of cycling cells with the acoustic schwannoma among the least proliferative and the metastatic carcinoma among the most proliferative. Within a given histotype, the Ki-67 LI may have prognostic and therapeutic implications for the individual patient. Already important for neuro-oncology research, the $\mathrm{Ki}-67 \mathrm{labeling}$ index should be added to the armamentarium of the clinical neuropathologist to complement the standard histopathologic diagnosis with a cytokinetic analysis of cellular proliferation.
\end{abstract}

RÉSUMÉ: La proportion de cellules en prolifération dans les tumeurs cérébrales humaines: analyse cytokinétique in situ avec l'anticorps monoclonal Ki-67. La croissance d'une tumeur est le résultat de la proportion relative de trois populations cellulaires: a) en phase proliférative, b) quiescente $\left(G_{0}\right)$ et c) complètement differenciées. Le compartiment des cellules en prolifération peut être évalué par immunocytochimie avec l'anticorps monoclonal Ki-67; cette méthode est facile, rapide et spécifique. Nous décrivons l'index de marquage (I.M.) obtenu sur 48 tumeurs cérébrales provenant de 47 malades opérés. Pour les tumeurs malignes l'I.M. s'est avéré très élevé, avec des valeurs limites entre $6.0 \%$ et $56.9 \%: 8.0 \pm 7.3$ pour l'astrocytome anaplasique; $10.1 \pm 4.2$ pour le glioblastome multiforme; 11.7 pour le germinome; $13.1 \pm 6.6$ pour le médulloblastome et $40.3 \pm 13.1$ pour les métastases. Par contre, pour les tumeurs à croissance lente l'I.M. $(P<.001)$ tourne autour de $1 \%: 0.4 \pm 0.6$ pour le schwannome du VIII nerf; $1.3 \pm 1.9$ pour l'adénome hypophysaire; $1.2 \pm 1.2$ pour le méningiome; <1 pour l'astrocytome bénin; 5.6 pour l'astrocytome pilocytique du cervelet. Les tumeurs cérébrales humaines peuvent être classées selon le pourcentage de cellules en prolifération: les schwannomes ont les valeurs les plus faibles tandis que les métastases ont les chiffres les plus élevés. Dans une même tumeur l'I.M. évalué par le Ki-67 peut avoir des implications pronostiques et thérapeutiques pour un malade en particulier. Cette méthode déjà importante pour la recherche en neuro-oncologie, devra être incoporée dans l'arsenal du neuropathologiste afin de compléter le diagnostic histopathologique par l'analyse cytokinétique de la prolifération cellulaire.

Can.J.Neurol. Sci. 1991; 18:12-17

Neoplasms grow because they contain a population of cells that is expanding as a result of cell division. 1,2 All tissues consist of 3 populations of cells: ${ }^{3}$ 1) cycling continuously dividing cells passing in sequence the various phases of the cell cycle $M$ (mitosis), $G_{1}$ (postmitotic), S-phase (DNA synthesis), and $G_{2}$ (premitotic); 2) terminal non-dividing cells that have left the cell cycle and are committed to differentiation and cell death; and 3 ) quiescent cells, $G_{o}$, that are neither cycling nor dying, but are dormant and can be induced to reenter the cycle by an appropriate stimulus. Normal tissues can be classified ${ }^{2}$ under headings of rapid, slow, or non-proliferating based upon the proportion of cells that incorporate a pulse of ${ }^{3} \mathrm{H}$-thymidine, i.e. the

From the Lady Davis Institute for Medical Research and the Departments of Neuroscience (AMT, SB), Pathology (FR), and Oncology (SB), Sir Mortimer B. Davis-Jewish General Hospital; the Department of Neurology and Neurosurgery, McGill University (AMT, SB), Department of Pathology, Ste. Justine Hospital (JM) and the Department of Pathology, University of Montréal (JM, FR), Montréal, Québec.

Received May 15, 1990. Accepted in final form October 11, 1990

Dr. Tsanaclis is a Visiting Scientist from the Department of Pathology, University of São Pãulo, São Pãulo, Brazil.

Reprint requests to: Dr. Steven Brem, Director, Neurosurgical Oncology, 233 East Erie Street, Suite 500, Chicago, Illinois, U.S.A. 60611 -2906 
labeling index (L.I.); a) rapid, $>5 \%$; b) slow, $\sim 1 \%$; or c) no proliferation, $\sim 0 \%$. Most normal tissues are in a steady state where cell growth is balanced by cell death. In neoplasms, an increase in the number of cycling cells in relation to cell loss has important implications in terms of the growth rate of the tumor, the prognosis for the patient, and susceptibility to chemotherapy and radiation therapy. 1,2

During the past two decades, Hoshino and co-workers have contributed to our understanding of cytokinetics in relation to the biology, ${ }^{4}$ therapy, ${ }^{4,5}$ and prognosis ${ }^{6,7}$ of human brain tumors. The normal tissue of the brain, the neurons, ${ }^{6}$ glia, ${ }^{6}$ and vascular endothelium, ${ }^{8}$ are non-proliferative; in no other organ does there exist such a sharp difference in the cytokinetics of normal and neoplastic tissue. ${ }^{6}$ Early studies of brain tumor cytokinetics were performed with a pulse of ${ }^{3} \mathrm{H}$-thymidine, a marker of the S-phase, given to the patient before surgical removal of the tumor. 2,5 Modern immunohistochemical techniques using commercially available monoclonal antibodies to BUdR, a thymidine analogue, provide a rapid, reproducible method to perform cell kinetics in situ in human $7,9,10$ and experimental ${ }^{8}$ brain tumors; the tumor labeling index is similar by either BUdR immunohistochemistry comparable to ${ }^{3} \mathrm{H}$-thymidine autoradiography. 8

$A$ recent advance in cytokinetic analysis of tumors is the introduction of a monoclonal antibody, $\mathrm{Ki}-67$, that recognizes a nuclear antigen expressed in all phases of the cell cycle, but is absent in quiescent $\mathrm{G}_{\mathrm{o}}$ cells. ${ }^{11.12}$ Thus Ki-67 provides a straightforward measure of the growth fraction of a tumor, the ratio between the number of cycling cells and the total number of cells. ${ }^{13}$ The values of $\mathrm{Ki}-67$ are naturally higher but parallel to those provided by BUdR; 14,15 by including $G_{1}, G_{2}$, and $M$-phase cells, Ki-67 staining allows a complete determination of cell cycle activity and gives more information than that revealed by flow cytometry, ${ }^{3} \mathrm{H}$-thymine uptake, or mitosis counting. ${ }^{16}$ Unlike isotopic thymidine or BUdR, $\mathrm{Ki}-67$ immunostaining can be performed on frozen sections without pre-operative administration of the agent and therefore is without risk to the patient. ${ }^{17}$ $\mathrm{Ki}-67$ immunostaining has proved useful for the evaluation of a variety of human brain tumors ${ }^{15,17-25}$ and tumors outside of the central nervous system (CNS). ${ }^{13,14,16,26-29}$ The objective of this study is to determine the growth fraction, by Ki-67 immunostaining, in a range of human CNS tumors.

\section{Materials and Methods}

\section{Tissue Preparation and Staining}

Thirty-five consecutive adult human tumors of the CNS, using a well-accepted system of classification, ${ }^{30}$ were studied prospectively and 13 pediatric tumors were used from stored frozen tissue. The tissue was sectioned immediately after removal; one portion was fixed in $10 \%$ buffered formalin for routine histopathology, the other was quick-frozen in isopentane suspended in liquid nitrogen at $-150^{\circ} \mathrm{C}$ for 1 minute. The frozen tissue blocks were stored at $-80^{\circ} \mathrm{C}$. Cryostat sections, $7 \mu \mathrm{m}$, were air-dried at room temperature for $1 \mathrm{hr}$, then fixed in methanolacetone $(1: 1)$ for $10 \mathrm{~min}$. at $-20^{\circ} \mathrm{C}$. After rinsing in phosphatebuffered saline (PBS, pH 7.6), endogenous peroxidase was blocked in $0.3 \% \mathrm{H}_{2} \mathrm{O}_{2}$ in PBS for $30 \mathrm{~min}$. After a thorough rinse in PBS, the avidin-biotin-peroxidase complex (ABC) method was used (Vectastain ABC Kit, PK4002, Vector Laboratories, Burlingame, $C A$ ), consisting of a preincubation with diluted nor- mal horse serum for $20 \mathrm{~min}$., followed by incubation in a humidified chamber with the monoclonal antibody Ki-67 (Dakopatts, USA) at 1:50 dilution for $60 \mathrm{~min}$. at room temperature. After rinsing in PBS, a biotinylated horse secondary antibody against mouse IgG and subsequently to avidin-biotin-peroxidasecomplex for $20 \mathrm{~min}$. each, sections were stained with 3,3'diaminobenzidine (Sigma Chemicals, St. Louis, MO), $10 \mathrm{mg}$ in $50 \mathrm{ml}$ PBS, and counterstained with Harris hematoxylin. For each section stained with $\mathrm{Ki}-67$, a negative control was performed by omitting the primary antibody, and substituting phosphate buffered saline.

\section{Determination of Ki-67 Labeling Index}

The LI was determined using a Bioquant Image Analyzer System (Wild Leitz, Montreal, PQ) composed of a video camera adapted to an Aristoplan microscope (Weild-Leitz, Montreal, $\mathrm{PQ}$ ) with transmission of the image to a video screen connected to a computer with specialized software. Under a $40 \mathrm{X}$ objective, the number of positive and negative cells were scored in 3 or more areas that were maximally positive, a total of 1500 to 2000 cells. A cell was classified positive when part or all of the nucleus was stained. The LI was defined as the proportion of positive cells in relation to the total number of cells evaluated. When the LI was close to zero, reported as $<1 \%$ in Tables 1 and 3, an arbitrary value of 0.02 was assigned to calculate the mean in a particular group.

\section{Results}

The Ki-67 monoclonal antibody provided a rapid, distinct, and clear nuclear staining of proliferating tumor cells in a variety of human CNS neoplasms (Figures 1-4). The LIs of 48 tumors are described together with the histological and clinical information in Tables 1-3. In general, malignant brain tumors high-grade gliomas, glioblastomas, medulloblastomas, and metastatic carcinomas - showed elevated LIs, ranging from 6.0 to 56.9. The LIs $(\bar{x} \pm S D)$ were: anaplastic astrocytomas $(n=3)$, $8.0 \pm 7.3$; glioblastomas $(n=11), 10.1 \pm 4.2$; medulloblastomas $(n=7), 13.1 \pm 6.6$; and cerebral metastases $(n=6), 40.3 \pm 13.1$.

These results were in marked contrast with slow-growing tumors $\mathrm{P}<.001$ : low-grade astrocytomas $(\mathrm{n}=2), \overline{\mathrm{x}}<1$; or extraaxial, nonmalignant tumors: acoustic schwannomas $(n=3), 0.4$ \pm 0.6 ; pituitary adenomas $(n=3), 1.3 \pm 1.9$; and meningiomas $(\mathrm{n}=4) 1.2 \pm 1.2$.

Thus, the human brain tumors could be ranked according to the percentage of cycling cells; the acoustic schwannomas were among the least proliferative and the metastases the most proliferative (Figure 5).

\section{Discussion}

The $\mathrm{Ki}-67$ mouse monoclonal antibody represents a rapid, reproducible, readily available, safe, sensitive method to specifically detect the growth fraction of normal, benign, and malignant cell populations. Ki-67 reacts with a nuclear antigen, present in nucleoli,28,29 and bound to DNA,31 expressed in proliferating cells and implicated in the maintenance of the proliferative state. ${ }^{29,31,32} \mathrm{Ki}-67$ will be valuable for further research into the biology of brain tumors. For example, transformed, neoplastic, proliferating cells can be removed from the cycling pool by depleting nutrients; ${ }^{3}$ deprived cells do not express the Ki-67 antigen. ${ }^{33}$ In solid tumors, the central parts often lack nutrients 
Table 1: Ki-67 Labeling Index (LI) for Central Nervous System Tumors.

\begin{tabular}{|c|c|c|c|c|c|}
\hline $\begin{array}{c}\text { Case } \\
\#\end{array}$ & Age & Sex & $\begin{array}{c}\text { Pathologic } \\
\text { Diagnosis }\end{array}$ & Location & LI (\%) \\
\hline 01 & 33 & M & Astrocytoma & Frontal & 0.22 \\
\hline 02 & 76 & $\mathbf{F}$ & $\begin{array}{l}\text { Anaplastic } \\
\text { astrocytoma }\end{array}$ & Temporo-parietal & 16.4 \\
\hline 03 & 32 & F & $\begin{array}{l}\text { Anaplastic } \\
\text { astrocytoma }\end{array}$ & Frontal & 3.5 \\
\hline 04 & 76 & $\mathbf{F}$ & Glioblastoma & Frontal & 9.2 \\
\hline 05 & 47 & $\mathbf{M}$ & Glioblastoma* & Frontal & 6.5 \\
\hline 06 & 59 & $\mathrm{M}$ & Glioblastoma & Temporal & 11.1 \\
\hline 07 & 70 & $\mathrm{~F}$ & Glioblastoma & Parieto-occipital & 6.1 \\
\hline 08 & 50 & M & Glioblastoma & Parieto-occipital & 13.0 \\
\hline 09 & 72 & $F$ & Glioblastoma* & Fronto-temporal & 6.0 \\
\hline 10 & 46 & $M$ & Glioblastoma & Parieto-occipital & 13.4 \\
\hline 11 & 54 & M & Glioblastoma* & Temporal & 15.0 \\
\hline 12 & 63 & $\mathbf{F}$ & Glioblastoma & Fronto-temporal & 6.4 \\
\hline 13 & 64 & M & Glioblastoma & Temporal & 6.4 \\
\hline 14 & 49 & $M$ & Oligoastrocytoma* & Frontal & 7.1 \\
\hline 15 & 49 & M & Oligoastrocytoma* & Frontal & 7.3 \\
\hline 16 & 37 & $\mathrm{~F}$ & Schwannoma & VIIIth nerve & zero \\
\hline 17 & 72 & $\mathrm{~F}$ & Schwannoma & VIIIth nerve & $<1$ \\
\hline 18 & 23 & $M$ & Schwannoma & VIIIth nerve & 1.1 \\
\hline 19 & 60 & M & Meningioma & Occipital & 0.9 \\
\hline 20 & 78 & M & Meningioma & Sphenoid wing & $<1$ \\
\hline 21 & 48 & $\mathbf{F}$ & Meningioma & Suprasellar & $<1$ \\
\hline 22 & 74 & M & Meningioma* & Falx & 2.9 \\
\hline 23 & 50 & M & $\begin{array}{l}\text { Hemangio- } \\
\text { pericytoma }\end{array}$ & Olfactory groove & 5.5 \\
\hline 24 & 39 & M & Invasive prolactinom & a Pituitary & 3.5 \\
\hline 25 & 77 & M & $\begin{array}{l}\text { Non-functioning } \\
\text { adenoma }\end{array}$ & Pituitary & $<1$ \\
\hline 26 & 64 & M & $\begin{array}{l}\text { Invasive } \mathrm{ACTH}- \\
\text { secreting adenoma }\end{array}$ & Pituitary & zero \\
\hline 27 & 34 & $M$ & Epidermoid cyst & Intraspinal & 6.0 \\
\hline 28 & 28 & $M$ & Germinoma & Suprasellar & 11.7 \\
\hline 29 & 66 & $M$ & Carcinoma & Temporal & 26.4 \\
\hline 30 & 81 & M & Carcinoma & Fronto-parietal & 43.9 \\
\hline 31 & 81 & M & Lymphoma & Parietal-occipital & 24.5 \\
\hline 32 & 49 & $\mathrm{~F}$ & Carcinoma & Parieto-frontal & 51.4 \\
\hline 33 & 54 & $M$ & Carcinoma & Occipital & 56.9 \\
\hline 34 & 33 & $M$ & Carcinoma & Frontal & 38.7 \\
\hline 35 & $5 y$ & $\mathrm{~F}$ & Medulloblastoma & Cerebellum & 12.5 \\
\hline 36 & $37 y$ & M & Medulloblastoma & Cerebellum & 15.9 \\
\hline 37 & $7 \mathrm{~m}$ & $M$ & Medulloblasto & Cerebellum & 6.9 \\
\hline 38 & $20 \mathrm{~m}$ & $M$ & Medulloblastoma & Cerebellum & 21.4 \\
\hline 39 & $18 y$ & $M$ & Medulloblastoma* & Frontal & 21.7 \\
\hline 40 & $2 y$ & $\mathrm{M}$ & Medulloblastoma & Cerebellum & 7.9 \\
\hline 41 & $33 y$ & $M$ & Medulloblastoma & Cerebellum & 6.4 \\
\hline 42 & $19 \mathrm{~m}$ & $\mathrm{~F}$ & $\begin{array}{l}\text { Primitive neuro } \\
\text { ectodermal tumor }\end{array}$ & Cerebellum & 11.1 \\
\hline 43 & $2 m$ & $\mathbf{M}$ & $\begin{array}{l}\text { Desmoplastic } \\
\text { ganglioglioma }\end{array}$ & Temporo-parietal & 8.9 \\
\hline 44 & $4 \mathrm{~m}$ & M & $\begin{array}{l}\text { Desmoplastic } \\
\text { ganglioglioma }\end{array}$ & Parietal & 5.0 \\
\hline 45 & $11 y$ & $\mathrm{~F}$ & Fibrillary astrocytom & a Brainstem & $<1$ \\
\hline 46 & $16 y$ & $M$ & Pilocytic astrocytom & a Cerebellum & 5.6 \\
\hline 47 & $6 y$ & $M$ & Anaplastic astrocytor & ma Temporal & 4.0 \\
\hline 48 & $14 y$ & M & Glioblastoma & Frontal & 17.7 \\
\hline
\end{tabular}

* recurrent tumor
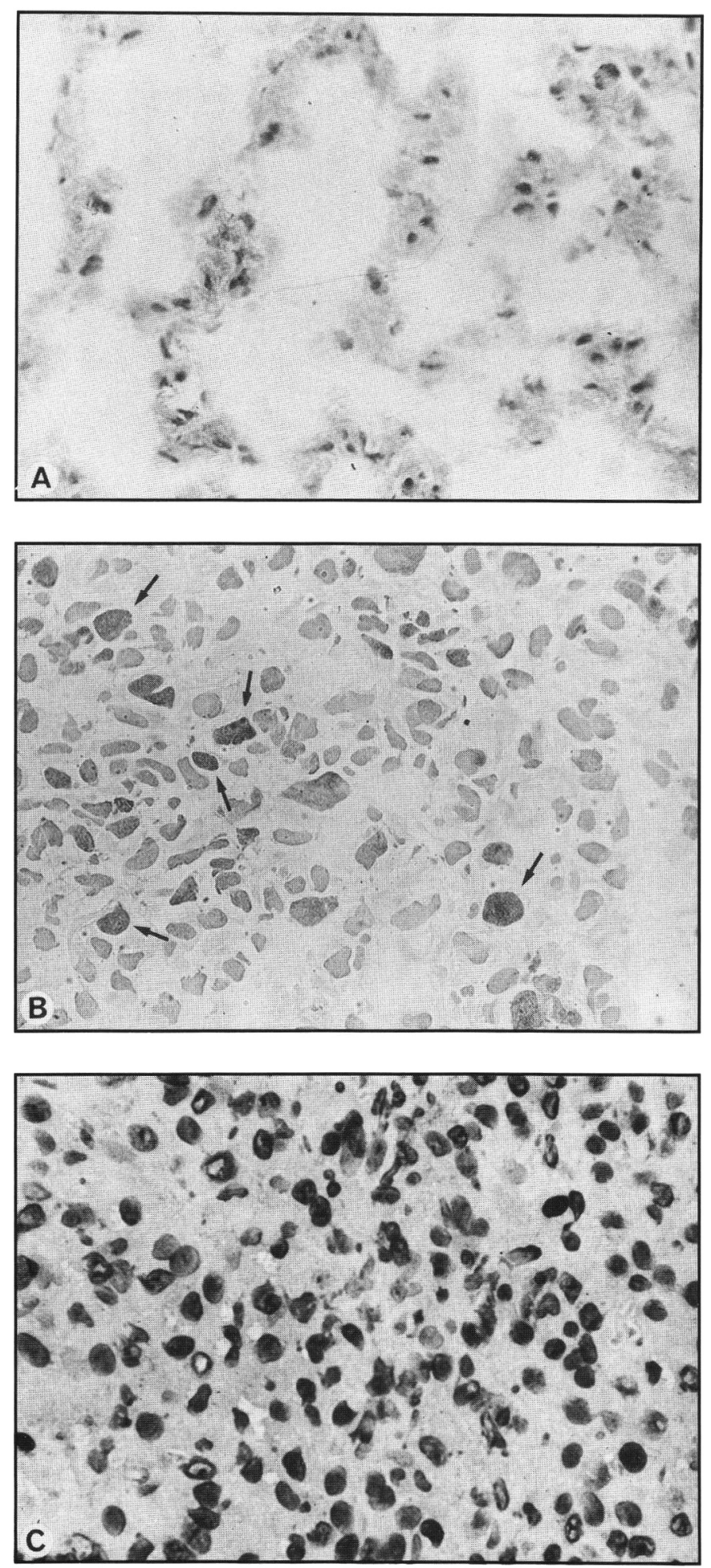

Figure I - Immunostaining of human astrocytomas with Ki67. The increased percentage of labeled muclei corresponds to the higher grade of malignancy. In $\mathrm{A}$, a low-grade astrocytoma, the nuclei are nonreactive for $K i-67$. The LI is less than one percent. In $\boldsymbol{B}$, an anaplastic astrocytoma, scattered neoplastic cells (arrows) show distinct immunopositive staining. In $\boldsymbol{C}$, a glioblastoma, there are numerous, darkly stained, immunopositive proliferating cells. $\boldsymbol{A}, \boldsymbol{B}$, original magnification, X400; $C$, original magnification, X630. 
and also show lower Lis than the peripheral areas. ${ }^{8}$ Novel therapeutic approaches based upon the manipulation of microenvironmental factors that stimulate or suppress cells proliferation have been proposed for human brain tumors. ${ }^{1} \mathrm{Ki}-67 \mathrm{might}$ prove useful to evaluate novel approaches designed to remove cells from the cycling, replicative pool.

The values of $\mathrm{Ki}-67 \mathrm{LI}$ in the current study fall within the range of previous series of human brain tumors (Figure 6). Variability in the LIs stems from two inherent limitations, one technical, the other biological. We and others ${ }^{16,24}$ assume that the proliferative potential is best gauged by the maximal observable change. Therefore, microscopic fields with the highest labeling were selected. An alternative approach is to sample several areas at random, ${ }^{20,22,26}$ but this method underestimates the growth fraction by combining active and quiescent areas. In gliomas, for example, once transformation begins, the growth rate of the tumor is determined by discrete anaplastic foci that overwhelm non-cycling areas. ${ }^{4}$ Furthermore, brain tumors are topographically heterogeneous and factors such as necrosis and

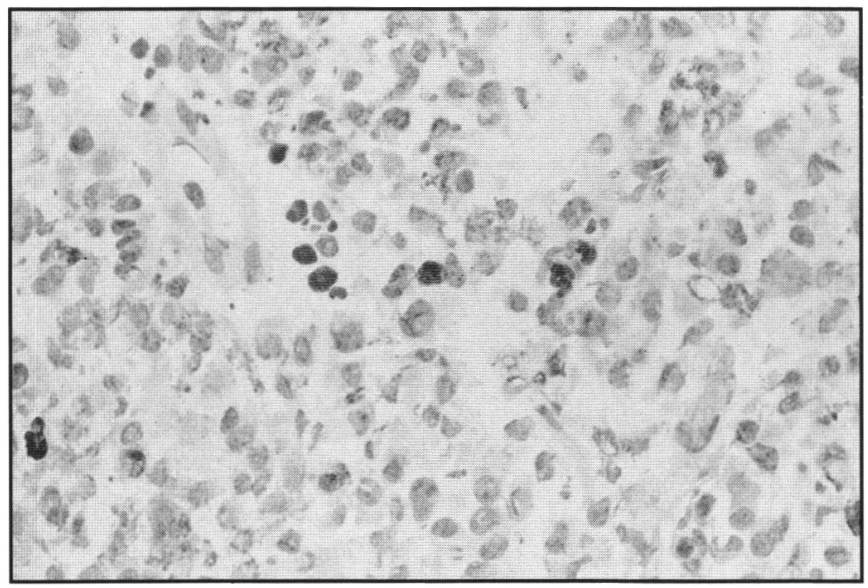

Figure 2 - Immunostaining of an oligoastrocytoma. There are numerous darkly-stained, proliferating, immunopositive cells; the tumor rapidly recurred in this patient. Original magnification, $X 400$.

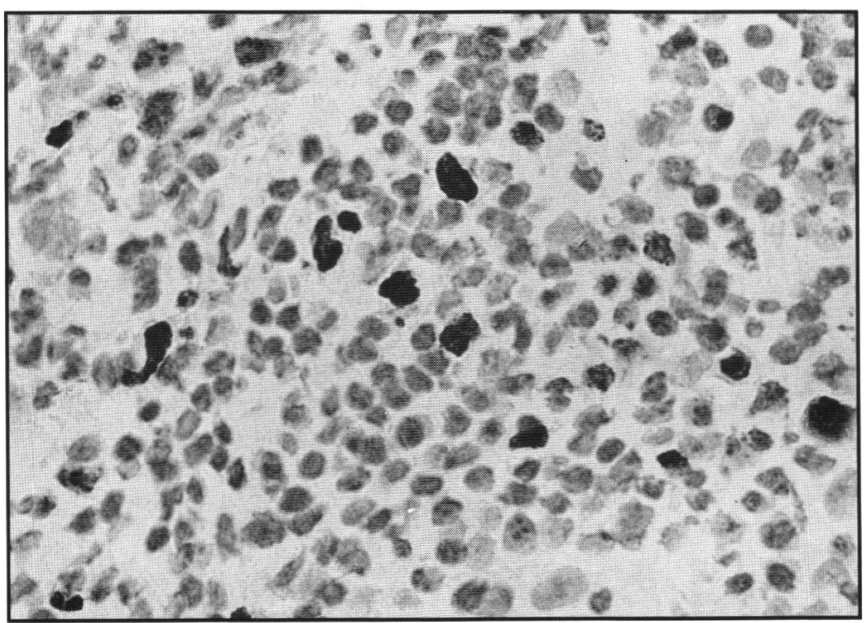

Figure 3 - Immunostaining of a germinoma. Darkly stained proliferating cells are seen. Original magnification, X630. proximity to vasculature modify the LI within an individual tumor. ${ }^{8}$ There is, however, a clear-cut distinction between the slow growing tumors with growth fractions near $1 \%$ and the rapidly proliferating glioblastomas, medulloblastomas, and carcinomas with LIs well above $5 \%$.

The very high growth fraction of metastatic carcinomas (range 26-57\%) has been noted previously. 17,21.24 In our series, the two patients with LIs greater than $50 \%$ had a very short post-operative survival of less than one month. Because the overall growth of the tumor is the net balance between the growth fraction and the cell loss, ${ }^{34}$ the rapid growth of metastatic carcinomas is offset, in part, by the cell loss fraction that can be as high

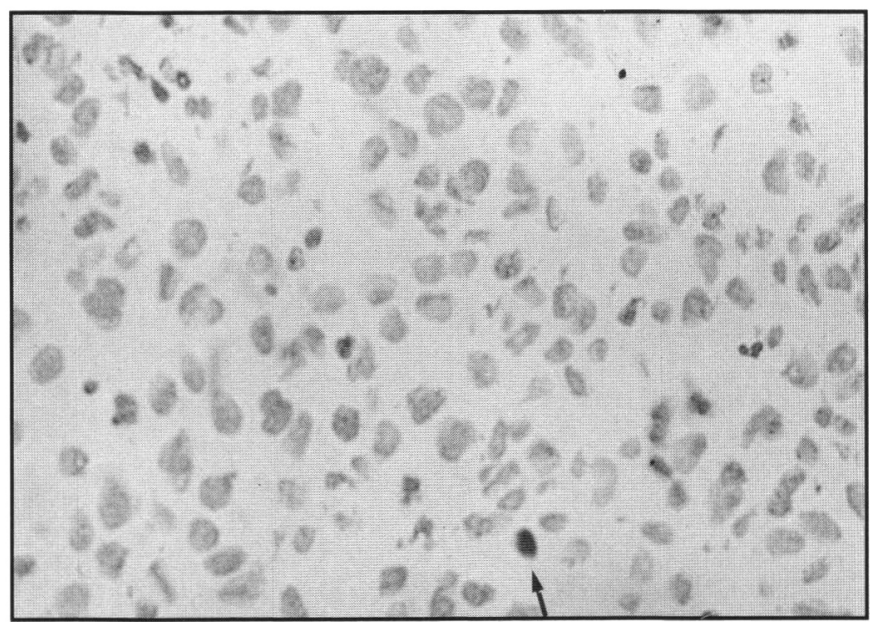

Figure 4 - Immunostaining of a prolactinoma. The majority of the cells are nonreactive. An occasional Ki-67 immunopositive cell (arrow) is visualized. Original magnification, $X 400$.

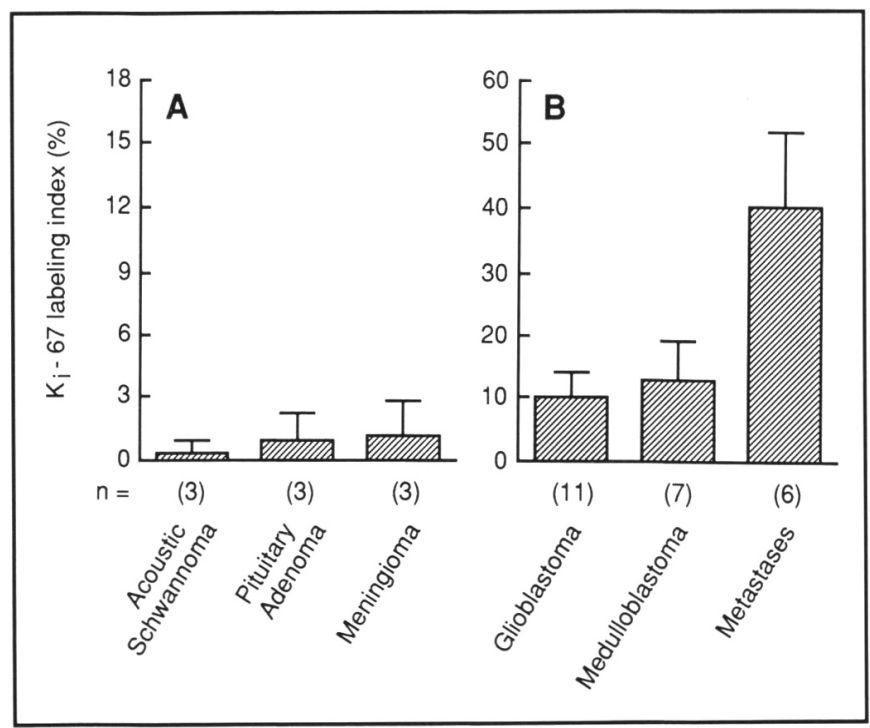

Figure 5-Human brain tumors can be grouped according to the percentage of (Ki.67 positive) cycling cells. In A, the benign tumors show a very slow turnover, the Ki-67 LI approaches one percent. Note the much higher values for the three groups of malignant tumors in B, with the LI averaging more than 10 percent. Each bar represents the mean $\pm S D$. 
as $90 \% .35$ The recent introduction of a marker for non-proliferating cells ${ }^{36}$ may prove useful to complement cytokinetic studies that currently focus only on the cycling pool.

For the gliomas, the slow growing tumors generally show $\mathrm{Ki}-67 \mathrm{LIs}$ that are below $1 \%$. The unexpectedly high LI $(5.6 \%)$ for a juvenile pilocytic astrocytoma (case \#46) of the cerebellum is consistent with that reported 10.17 and suggests an aggressive variant, ${ }^{10}$ since values less than $1 \%$ have also been assigned to pilocytic astrocytomas. 22

It is likely, but as yet unproven, that an elevated LI predicts an early recurrence. The tissue from case \#14 was diagnosed as a mixed oligoastrocytoma with anaplastic changes in the oligodendrocytic component; case \#15 was from the same patient, six months later, with the identical histologic diagnosis at recurrence. The LIs were nearly the same from both surgical specimens. The high LI, in retrospect, may have reflected the potential for early recurrence. Previous studies have reported that oligodendrogliomas and its anaplastic variant $10,17,19$ as well as mixed gliomas $17,19-21$ exhibit LIs higher than $1 \%$, and as high as $14.4 \% .^{21}$

The medulloblastomas had $\mathrm{Ki}-67$ labeling indices similar to those of adult glioblastomas (Figure 5), and were comparable to the values previously reported. ${ }^{10}$ Prolonged storage did not alter the expression of the Ki-67 antigen, as suggested, 22 but instead enabled the reproducible labeling of medulloblastomas and other pediatric tumors.

The germinoma showed an elevated LI (11.7\%). The immunostaining was mainly in the small cell population. We were unable to find a previous report of $\mathrm{Ki}-67$ immunostaining of a germinoma for comparison.

Recent studies with flow cytometry support the concept that a higher number of cycling cells predicts a poor prognosis. ${ }^{37} \mathrm{By}$ contrast, the benign tumors generally show a LI less than $1 \%$ (Tables 1-3). Schwannomas are known to have low growth fractions. 15,17,19,21,22 A few notable exceptions, however, did occur. For example, in one pituitary adenoma (case \#24) the LI was $3.5 \%$; a recurrent meningioma (case \#22) showed a LI of $2.9 \%$. Infiltration, anaplasia, and recurrences of tumors are linked to

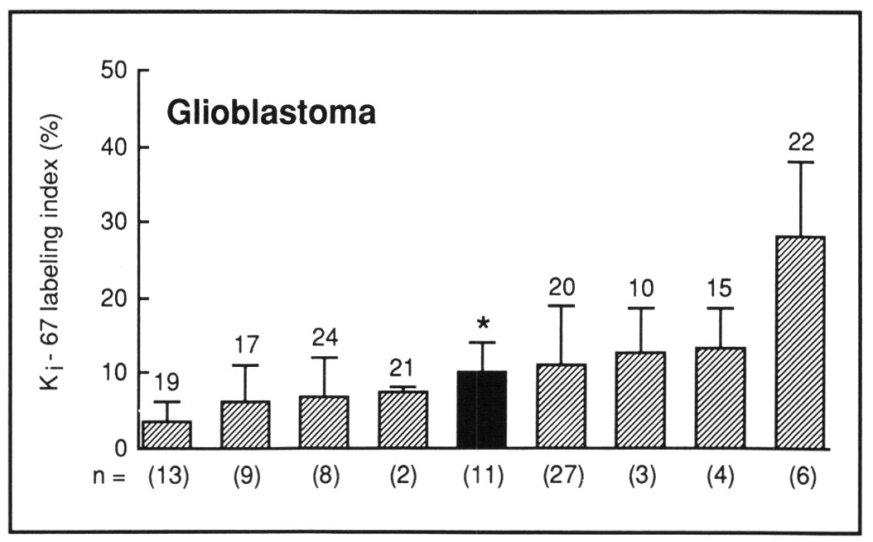

Figure 6-Composite summary of Ki-67 labeling indices $(\Sigma \pm$ $S D)$ reported in the literature for glioblastoma. The numbers in parenthesis represent the number of tumors studied, and the number on top of the bar refers to the citation in the list of references. The shaded column in the middle $\left(^{*}\right)$ denotes the current series. elevated LIs. 14,21,23,24,38,39 When compared to noninvasive adenomas, the $\mathrm{Ki}-67$ labeling index is higher in invasive adenomas ${ }^{18}$ as demonstrated in case \#24. The paradoxically low $\mathrm{LI}$ in case \#26 could relate to the limitations of tissue sampling.

There is increasing evidence that the LI carries clinical significance, the higher the $\mathrm{LI}$ the more ominous the prognosis. $6,7,39$ The course of a brain tumor is influenced by multiple factors such as size, location, age, degree of edema, necrosis, ${ }^{7}$ vascularity, ${ }^{7}$ and invasiveness. ${ }^{40}$ Nevertheless, the cellular proliferative potential, determined by $\mathrm{Ki}-67$ immunohistochemistry, should be added to the armamentarium of the neuropathologist in the routine assessment of surgical material to provide dynamic cytokinetic data that will complement classical histopathologic diagnosis based upon morphology alone.

\section{ACKNOWLEDGEMENTS}

We thank David Ivancic and Marguerite Wotoczek for expert technical assistance; Shirley Entis for the clinical data; Anne Shirley Luck, Hinda Packard and Francine Dotson for typing the manuscript. The gift of the Bioquant Image Analyzer by the Dalse Club is gratefully acknowledged.

Supported by grants from the Medical Research Council of Canada and the Cancer Research Society, Inc. and a Chercheur-Boursier Clinicien Award of the Fonds de la Recherche en Santé du Québec (to S.B.).

\section{REFERENCES}

1. Rosenblum ML, Berens ME, Rutka JT. Recent perspectives in brain tumor biology and treatment. Clin Neurosurg 1989; 35: 314-335.

2. Tannock IF. Tumor growth and cell kinetics. In: Tannock IF, Hill RP, eds. The Basic Science of Oncology. New York: Pergamon Press 1987; 140-159.

3. Baserga R. The cell cycle. N Engl J Med 1981; 304: 453-459.

4. Hoshino T. A commentary on the biology and growth kinetics of lowgrade and high-grade gliomas. J Neurosurg 1984; 61: 895-900.

5. Hoshino T, Wilson CB, Rosenblum ML, et al. Chemotherapeutic implications of growth fraction and cell cycle time in glioblastomas. J Neurosurg 1975; 43: 127-135.

6. Hoshino $\mathrm{T}$, Wilson $\mathrm{CB}$. Cell kinetic analysis of human malignant brain tumors (gliomas). Cancer 1979; 44: 956-962.

7. Hoshino T, Rodriguez LA, Cho KG, et al. Prognostic implications of the proliferative potential of low-grade astrocytomas. J Neurosurg 1988; 839-842.

8. Brien SE, Zagzag D, Brem S. Rapid in situ cellular kinetics of intracerebral tumor angiogenesis using a monoclonal antibody to bromodeoxyuridine. Neurosurgery 1989; 25: 715-719.

9. Yoshii Y, Maki Y, Tsuboi K, et al. Estimation of growth fraction with bromodeoxyuridine in human central nervous system tumors. J Neurosurg 1986; 65: 659-663.

10. Murovic JA, Nagashima T, Hoshino T, et al. Pediatric central nervous system tumors: A cell kinetic study with bromodeoxyuridine. Neurosurgery 1986; 19: 900-914.

11. Gerdes J, Lemke H, Baisch H, et al. Cell cycle analysis of a cell proliferation-associated human nuclear antigen defined by the monoclonal antibody Ki-67. J Immunol 1984; 133: 1710-1715.

12. Gerdes J. An immunohistological method for estimating cell growth fractions in rapid histopathological diagnosis during surgery. Int J Cancer 1985; 35: 169-171.

13. Lelle RJ, Heidenreich W, Stauch G, et al. The correlation of growth fractions with histologic grading and lymph node status in human mammary carcinoma. Cancer 1987; 59: 83-88.

14. Sasaki K, Matsumura K, Tsuji T, et al. Relationship between labeling indices of $\mathrm{Ki}-67$ and $\mathrm{BrdUrd}$ in human malignant tumors. Cancer 1988; 62: 989-993.

15. Nishizaki T, Orita T, Furutani Y, et al. Flow-cytometric DNS analysis and immunohistochemical measurement of $\mathrm{Ki}-67$ and BUdR labeling indices in human brain tumors. J Neurosurg 1989; 70: 379-384. 
16. Schwartz BR, Pinkus G, Bacus S, et al. Cell proliferation in nonHodgkin's lymphomas: Digital image analysis of $\mathrm{Ki}-67$ antibody staining. Am J Pathol 1989; 134: 327-336.

17. Burger PC, Shibata T, Kleihues $P$. The use of the monoclonal antibody $\mathrm{Ki}-67$ in the identification of proliferating cells: Application to surgical neuropathology. Am J Surg Pathol 1986; 10:611-617.

18. Knosp E, Kitz K, Perneczky A. Proliferation activity in pituitary adenomas: Measurement by monoclonal antibody Ki-67. Neurosurgery $1989 ; 25: 927-930$.

19. Patsouris E, Stocker U, Kallmeyer V, et al. Relationship between $\mathrm{Ki}-67$ positive cells, growth rate and histological type of human intracranial tumors. Anticancer Res 1988; 8: 537-544.

20. Zuber $P$, Hamou $M-F$, de Tribolet $N$. Identification of proliferating cells in human gliomas using the monoclonal antibody $\mathrm{Ki}-67$. Neurosurgery 1988; 22: 364-368.

21. Deckert M, Reifenberger G, Wechsler W. Determination of the proliferative potential of human brain tumors using the monoclonal antibody Ki-67. J Cancer Res Clin Oncol 1989; 115: 179-188.

22. Giangaspero $F$, Doglioni $C$, Rivano $M T$, et al. Growth fractions in human brain tumors defined by the monoclonal antibody $\mathrm{Ki}-67$. Acta Neuropathol (Berl) 1987; 74: 179-182.

23. Roggendorf W, Shuster T, Peiffer J. Proliferation potential of meningiomas determined with the monoclonal antibody Ki-67. Acta Neuropathol (Berl) 1987; 73: 361-364.

24. Morimura T, Kitz K, Budka $\mathrm{H}$. In situ analysis of cell kinetics in human brain tumors. A comparative immunocytochemical study of S-phase cells by a new in vitro bromodeoxyuridine-labeling technique, and of proliferating pool cells by monoclonal antibody Ki-67. Acta Neuropathol 1989; 77: 276-282.

25. Raghavan R, Steart PV, Weller RO. Cell proliferation patterns in the diagnosis of astrocytomas, anaplastic astrocytomas and glioblastoma multiforme: a Ki-67 study. Neuropathol Appl Neurobiol 1990; 16: 123-133.

26. Shepherd NA, Richman PI, England J. Ki-67 derived proliferative activity in colorectal adenocarcinomas with prognostic correlations. J Pathol 1988; 155: 213-219.

27. Kaudewitz P, Braun-Falco O, Ernst M, et al. Tumor cell growth fractions in human malignant melanomas and the correlation to histopathologic tumor grading. Am J Pathol 1989; 134: 1063-1068.

28. Verheijen R, Kuijpers HJH, Schlingemann RO, et al. Ki-67 detects a nuclear matrix-associated proliferation-related antigen. I.
Intracellular localization during interphase. J Cell Sci 1989; 92: 123-130.

29. Guillaud P, du Manoir S, Seigneurin D. Quantification and topographical description of $\mathrm{Ki}-67$ antibody labelling during the cell cycle of normal fibroblastic (MRC-5) and the mammary tumor cell lines (MCF-7). Anal Cell Pathol 1989; 1: 25-39.

30. Russell DS, Rubinstein LJ. Pathology of Tumors of the Nervous System; 5th edition. Baltimore: Williams and Wilkins 1989.

31. Sasaki K, Murakami T, Kawasaki M, et al. The cell cycle associated change of the $\mathrm{Ki}-67$ reactive nuclear antigen expression. J Cell Physiol 1987; 133: 579-584.

32. Falini B, Flenghi L, Fagioli M, et al. Evolutionary conservation in various mammalian species of the human proliferation-associated epitope recognized by the Ki-67 monoclonal antibody. J Histochem Cytochem 1989; 37: 1471-1478.

33. Verheijen R, Kuijpers $\mathrm{HJH}$, van Driel R, et al. Ki-67 detects a nuclear matrix-associated proliferation-related antigen. II. Localization in mitotic cells and association with chromosomes. J Cell Sci 1989; 92: 531-540.

34. Wylie AH. The biology of cell death in tumors. Anticancer Res 1985; 5: 131-136.

35. Kerr KM, Lamb D. Actual growth rate and tumor cell proliferation in human pulmonary neoplasms. Br J Cancer 1984; 50: 343-349.

36. Wang E, Krueger JG. Application of a unique monoclonal amibody as a marker for nonproliferating subpopulations of cells of some tissue. J Histochem Cytochem 1985; 65: 587-594.

37. McKeever PE, Feldenzer JA, McCoy JP, et al. Nuclear parameters as prognostic indicators in glioblastoma patients. J Neuropathol Exp Neurol 1990; 49: 71-78.

38. Reifenberger G, Deckert M, Wechsler W. Immunohistochemical determination of protein kinase $C$ expression and proliferative activity in human brain tumors. Acta Neuropathol 1989; 78: 166175.

39. Hoshino T, Nagashima T, Cho KG. Variability in the proliferative potential of human gliomas. J Neuro-Oncol 1989; 7: 137-143.

40. Brem S, Tsanaclis AMC, Zagzag D. Anticopper treatment inhibits pseudopodial protrusion and the invasive spread of $9 \mathrm{~L}$ gliosarcoma cells in the rat brain. Neurosurgery 1990; 26: 391-396. 